\title{
The rise of the local food movement and its impact on rural economies: With examples from the Region of Durham
}

\author{
Stacey Jibb, B.A. \\ Rural economies across North America continue to see the positive impacts of the rise of \\ the local food movement and the evolution of the local food system. Local food is a fluid \\ definition impacted by several factors. Government policy, geography and the personal \\ relationships that develop between producer and consumer all play a part in shaping what \\ is local. This has altered how consumers interact with the local food economy and has given \\ rise to direct-farm marketing and agri-tourism as ways to participate in the local food \\ system. Using examples from northern Durham Region, this paper examines how rural \\ economies are impacted by the growing demand for access to local food and how that \\ translates into direct impacts for the local economy.
}

Keywords: local food, local food movement, rural economies, direct-farm marketing, food economy

\section{Introduction}

This paper will examine the impact of the Local Food Movement on rural economies with examples from the Region of Durham. It will begin by examining several different topic areas that help to form a fluid definition of 'local food'. This is an important step as it offers greater clarity and meaning to 'local food' as it pertains to this paper. Secondly, this paper will delve into a discussion of what motivates people to buy local and what the local food movement looks like in both Canada and Ontario. Finally, this paper will go a step further than the consumer level benefits by examining how aspects of the local food system positively contribute to the health of rural economies, specifically through analyzing direct farm marketing as a tool for rural development delving into examples of success stories in the Region of Durham.

\section{Is there a definition for 'local food'?}

It is very difficult to find a definition of local food that is suitable for everyone. There are different definitions based on who you are, where you live, and what local food means in the context of your community, region and province. Rather than settling on one definition for 'local food', this paper will examine different facets of the local food system that contribute to the overall meaning, the only exception being government definitions. At a government level, clear definitions are needed as they are important for the purposes of policy development and implementation, legislation and the administration of funding programs. Provincially, Ontario defines local food in Bill 36, Local Food Act 2013, as "food produced or harvested in Ontario, 
including forest or freshwater food, and subject to any limitations in the regulations, food and beverages made in Ontario if they include ingredients produced or harvested in Ontario" (Bill 36, 2013).

In 2013, the Canadian Food Inspection Agency (CFIA) announced an overhaul of their food labelling policy and launched the Food Labelling Modernization Initiative with the overall objective of developing a more modern food labeling system that responds to current and future challenges. As part of this new initiative, an 'interim policy' for local food was developed, recognizing local food as: "food produced in the province or territory in which it is sold, or food sold across provincial borders within $50 \mathrm{~km}$ of the originating province or territory" (Food Labelling Modernization Initiative, 2016). This demonstrates an attempt on behalf of the Federal Government to recognize the need to adapt to the new overall food systems which places increasing importance on local food.

When reading the CFIA's definition of local food, it is important to note they identified $50 \mathrm{~km}$ distance as a benchmark. It is important to keep this in mind when examining other facets of what defines the local food narrative starting with geography. In terms of local food, geography is the distance from producer to consumer; simply it is the distance between where the food is grown and where the food is purchased. This is not to be confused with the concept of locality foods, which are foods or brands associated with a specific locality or region but often source inputs nationally or internationally (Brian, 2016). An example of this in Durham Region is Algoma Orchards Ltd.; a Durham Farm Fresh member known for growing apples, but they also import many apples from overseas and sell them in their Gourmet Market.

Along with geography, it is also important to consider population density and future population growth as part of the local food narrative. What is considered local in a sparsely populated area might be very different from what is considered local in a heavily populated area (Martinez, 2010). The Region of Durham provides a prime example of this:

Figure 1 - Percentage of population in Durham Region (1976 to 2011)
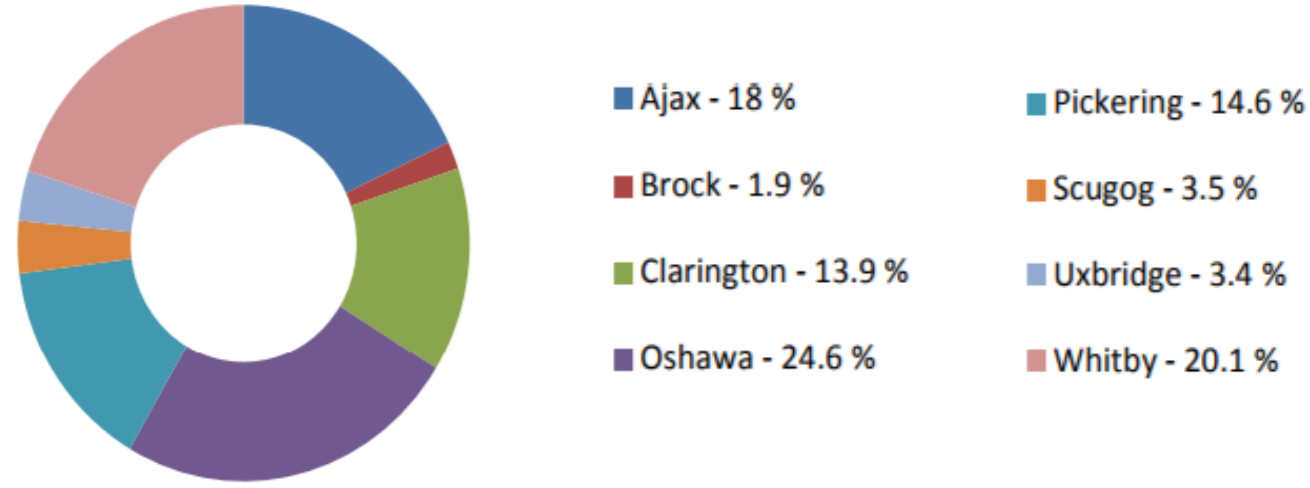

Source: Durham Region Health Department. (July 2016). Population at a Glance. https://www.durham.ca/departments/health/health_statistics/popAtAGlance.pdf. 
The population in Ontario increased by 55.5 per cent and the Greater Toronto Area (GTA) increased by 90.4 percent with Durham ranking third amongst other GTA municipalities for growth. Oshawa, Whitby and Ajax saw the highest population growth in Durham Region during this period.

There are eight municipalities with the Region of Durham, five of which are located along the Highway 401 corridor and are directly on the shores of Lake Ontario. The remaining three municipalities are in the northern portion of the region. Compared to the southern municipalities, the northern municipalities are sparsely populated making up just 9\%, of Durham Region's 661,190 population (Durham Region Health Department, 2016). Therefore, food produced in this area of the region is generally considered to be local even though much of it will be purchased by consumers who do not live in that municipality and are more than $50 \mathrm{~km}$ away. The Region of Durham covers an area of 2,523 km2 spanning $80 \mathrm{~km}$ from south to north and over $90 \mathrm{~km}$ from east to west (Figure 2).

Figure 2 - Map of Durham Region

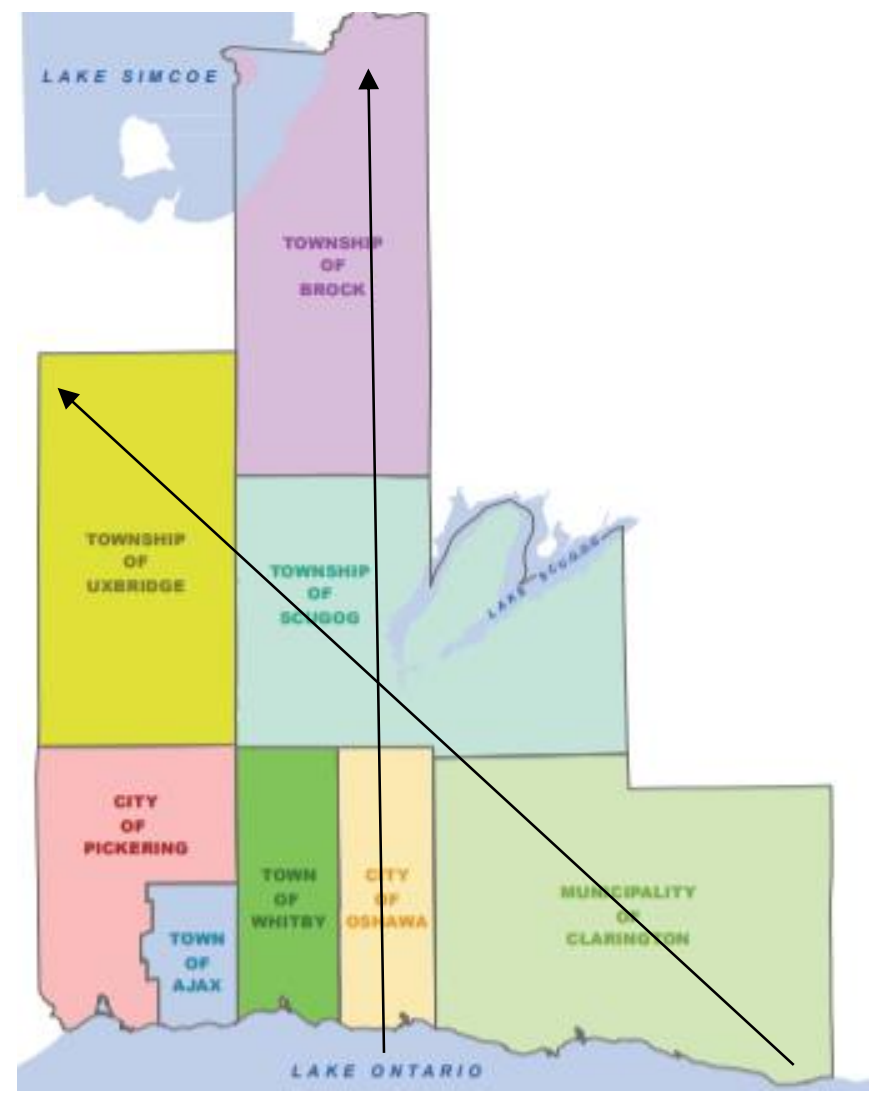

Source: Discovering Durham Maps. (2017). yourDurhamMap. https://www.durham.ca/en/discoveringdurham/maps-gis.aspx 
Another characteristic of the local food narrative is production methods. Often this can indicate the use of organic practices: there is a perception that local food production utilizes sustainable production methods and/or reduced use of herbicides and pesticides. Other characteristics include: fair farm labour practices, attention to animal welfare, personal characteristics and ethics of the producer, association with small farms, community feel and a personal level supply chain. All these characteristics point to the importance of the relationship formed when the consumer can purchase their food directly from the producer (Martinez, 2010).

\section{Motivations and obstacles for consumers when buying local food}

Many of the characteristics described above are attattributable to what motivates people to buy local. In 2016 the Canadian Centre for Food Integrity conducted a survey to determine public trust in the Canadian Food System. Over 2,500 respondents completed the web-based survey between February and March of 2016. Results demonstrated that Canadians know very little to nothing about farming in Canada. They do, however, have strong opinions about many food systems issues. Some of these issues include concerns about the rising cost of food and keeping healthy local food affordable. One of the solutions to these issues is connecting consumers with producers, this leads to meaningful conversations about how food is grown (Canadian Public Trust Research, 2016).

Increasingly, consumers appreciate the fact that they can purchase locally and are able to develop a relationship with the producer. This relationship can lead to open and honest conversations about where food comes from and how it is produced, despite a potential lack of knowledge on behalf of the consumer.

A study conducted in the United Kingdom at the University of Leicester corroborates the findings of the Canadian Centre for Food Integrity survey. In 2013, the University of Leicester's Cultural Production Research Group conducted a survey asking respondents, 'What does local food mean to you?' The summary of findings stated the ideal meaning of local food varied for different people but generally revolved around specific places and people. Findings also suggested that people lack the knowledge about where food is from or where to purchase local food (Bain et al., 2013). This again links local food system success with the development of producer/consumer connection.

An article published by the University of Vermont in 2010 lists the following top ten reasons to buy local food (Grubinger, 2010):

1. Locally grown food tastes and looks better,

2. Local food is better for you,

3. Local food preserves genetic diversity,

4. Local food is safe,

5. Local food supports local families,

6. Local food builds communities, 
7. Local food preserves open space,

8. Local food keeps taxes down,

9. Local food benefits the environment and wildlife,

10. Local food is an investment in the future.

There are other motivations and benefits for buying local aside from supporting local farmers; it also reduces environmental impact and increases flavor as well as quality. Buying local, no matter what your definition of local is, reduces food miles providing access to fresher more flavorful food as food consumed soon after it is harvested. For example, produce forced to survive long distance transportation is harvested prematurely and ripens in transit reducing flavour. Consumers are encouraged to eat seasonably, to enjoy and learn about what is in season in their area. As consumers learn to eat in accordance with the agricultural harvest calendar it creates knowledge and awareness of the agricultural system in Canada. Lastly, the economic benefits of purchasing local are understood by consumers; when food produced and purchased locally the farmer retains a larger portion of their revenue (Reynolds, 2016).

\section{Canada's Local Food Movement}

The term locavore, one who eats foods grown locally whenever possible, was the word of the year in 2007 (Merriam-Webster, 2005). Many journalists, researchers and academics consider this a turning point for the local food movement, when the purchase and consumption of locally grown food became an established mainstream idea as opposed to a small foodie movement. This term was popularized further by Sara Elton's book Locavore: From Farmers' Fields to Rooftop Gardens - How Canadians are Changing the Way We Eat published in 2010.

In the book, Elton travels the country to find stories of local food that has not travelled several hundred miles to reach its destination. Elton refers to herself as a "twenty-first-century urban hunter gatherer" and describes the overall concept of the book explaining there is an abundance of food in Toronto but to find local food she must travel outside of the city. Elton describes her mindset when shopping for local produce, "if I can grow it here I won't buy it from there" (Elton, 2010). This is at the crux of the local food movement, a shift in consumer awareness where consumers begin to question where their food comes from, searching out product of origin labelling and recognizable 'buy local' campaigns they trust to represent local food at a Provincial level.

Elton also writes about the local food movement in the Canadian Encyclopedia where she refers to Canada's local food movement as one that, "champions regional food system in which farmland is saved from urban and industrial sprawl," and for people who, "know where their food comes from [and are]engaged in eating seasonally" (Elton, 2010). In the article, Elton provides a history of the local food movement: she attributes youth and their rapidly increasing interest as the drivers, for the creation of the Toronto Food Policy Council in 2004. The major shift happened when food began to become part of one's personal identity; the growing 
economic divide and growing concern about climate change and the local environment accelerated this shift. These were new moral incentives to reduce food miles and to ensure that everyone had access to healthy produce despite where they live.

In 2009, Canadians Alissa Smith and J.B. MacKinnon, released the 100 Mile Diet. The book chronicled the challenges the two authors faced trying to eat only foods produced within a onehundred-mile radius of their Vancouver, British Columbia home. According to Sara Elton, the book helped to shed light on the failings of the industrial food system, including increasing obesity rates and harmful environmental impacts. For Elton, it was this book that began a national conversation in Canada about where food comes from and what it means to eat local in the twenty-first-century (2010).

\section{Local food on the rise in Ontario}

A report released in 2014 stated ninety-two per cent of Ontario food shoppers recognize and value the Foodland Ontario symbol. Foodland Ontario is a consumer promotion program first launched in 1977 by the Ontario Ministry of Agriculture, Food and Rural Affairs (OMAFRA). Foodland Ontario's mission is to spread the message about the nutritional, taste and economic benefits of buying Ontario produced food to all people in Ontario, particularly grocery store shoppers. Since it began, Foodland Ontario has been working closely with producers to help spread the word about buying local, in part, by encouraging relationships with producers and consumers. Foodland Ontario encourages consumers to get to know the people behind their products and uses this as one of their cornerstone marketing tools. Foodland helps in other ways to build its brand recognition and encourage the local food movement by providing marketing and promotional materials to grocery stores who stock local products, by developing seasonal availability guides, liaising with the media and journalists and conducting market research (Foodland Ontario, 2012).

Overall, the success of the Foodland Ontario program continues to have an impact on consumers across Ontario. With opportunities such as Foodland Ontario Partnership Funding available, small communities can host and celebrate local food in their area. An example of this in Durham Region is the Farmers of Uxbridge event. The town of Uxbridge is a small rural town which is also within proximity to large urban centers such as Newmarket, Aurora, Richmond Hill, Pickering and Ajax; all of which have a combined population of just over six million. The goal of the event is to encourage consumers to be conscious of where they can buy local products, when they are available and learn more about farming in the Township. The event has highlighted the wide variety of farmers and producers of agricultural related products and food from across the Township. Consumers get the opportunity to meet local farmers to ask questions about where their food comes from and how it is grown. The event also features live animals, farm equipment with a farm safety component, and booths for organizations that promote youth engagement in agriculture like the $4 \mathrm{H}$ club and Junior Famers. 
In 2016, Foodland Ontario provided Event Partnership Funding to assist with the Farmers of Uxbridge event. Much of the funding was used for marketing and promotions, the Foodland logo was leveraged as a promotional tool being featured on social media through Twitter and Facebook and in print advertising for the event. Estimates suggest that event marketing reached almost 30,000 people, helping to increase awareness of local food in the area. The event itself saw over 1,000 visitors who provided almost 50 consumer impressions which were overwhelmingly positive. The Foodland Ontario marketing tactics were beneficial to Farmers of Uxbridge event by helping to almost double attendance numbers from the previous year increasing overall awareness about local food and continuing to encourage local food consumption in rural Ontario.

Along with the Foodland Ontario program, OMAFRA continues to focus on investments in the agri-food sector to help maintain the momentum of the local food movement. According to the 2015-2016 Ontario Local Food Report in two years Ontario's agri-food industry contributed \$1.3 billion to the overall GDP and created 34,000 jobs. Other notable achievements are:

- Farmer's Markets have increased by nearly 300 per cent (Canada, 2016) since the late 1980's and early 1990's, now totaling 175 throughout the province (About Farmers Markets, n.d.)

- Approximately 300 members of the Ontario Farm Fresh Marketing Association, most of whom are employing direct farm marketing tactics

- 81 per cent of Ontario shoppers indicate that they can identify Ontario grown fruits and vegetables in the grocery stores (partially attributed to the use of the Foodland Ontario marketing)

- 51 per cent of Ontario's principal grocery shoppers include local grown produce or food items in a minimum of one meal each day

- 78 percent of Ontario's principal grocery shoppers report that they include locally grown produce or food items in a least one meal each week (Canada, 2016)

\section{Economic Impacts of the Local Food Movement}

It has been established that the local food movement in Canada started in the early 2000's. As a result, there is little evidence about the long-term impacts local food movement has had on small towns and rural economies. It takes several years of data collection and ongoing analyses to see results of significance. Therefore, many of the impacts discussed in this paper are based on qualitative measures and some quantitative results from studies and research conducted in the United States. 
The local food movement has been strongly associated with the concept of direct farm marketing. The Ontario Ministry of Agriculture, Food and Rural defines direct farm marketing as:

Direct farm marketing requires being much more involved in the marketing and sale of a product to the end user - the consumer - than conventional primary production agriculture. Unlike traditional methods of selling products, such as wholesale into the marketplace, direct farm marketing allows for greater control by the producer into the production and selling of a product, including the ability to be a price maker - not a price taker (Collins, Kelly and Pate, 2011).

Some of the activities that OMAFRA associates with direct farm marketing include:

- On-farm activities such as roadside stands, farm markets/shops, pick-your-own operations and community-supported agriculture (CSA)

- Off-farm activities such as being a vendor at one or several farmers' markets or selling through online sales and direct delivery (Collins, Kelly and Pate, 2011).

At the most basic level, the rise of the local food movement impacts rural economies and small towns by retaining revenue generated in the communities. The New Economics Foundation in the United Kingdom conducted a comparison study that found when items were purchased locally it nearly doubled the amount of money circulated in a community as opposed to being purchased at supermarkets or chain stores (Schwartz, 2009). Often money leaves small communities by consumers travelling to urban centers to purchase non-local goods.

The relationship between consumer and producer has given rise to the local food movement. Purchasing food directly from the producer carries an economic impact, as it ensures a direct flow of income from the consumer to producer particularly through direct farm marketing. Many consumers today who identify with the local food movement feel compelled to support local family run businesses as opposed to supermarkets and chain stores. When farmers sell directly to the consumer, they retain a greater portion of the value-added costs typically captured by the middleman (large firms) further down the supply chain. This helps preserve and sustain small farms and rural communities (Brian, 2012). Estimates state, buying local keeps approximately 65 per cent of each dollar within the community whereas buying at large chains only keeps about 40 per cent of each dollar in the community (Brian, 2012).

In his article, Direct Farm Marketing as a Rural Development Tool, Fed Gale of the United States Department of Agriculture, writes that economic impacts of local food via direct farm marketing also comes from the recreational aspect of purchasing local (2013). Gale states that by adding a recreational component to food consumption many direct-marketing enterprises draw urban people to farm communities to connect with their rural roots. These visitors may spend additional dollars on restaurant meals, shopping, or other services. As such, 'agricultural tourism' may have a 'multiplier effect' on local economies (Gale, 2013). 


\section{Economic Success Stories of Local Food in Durham Region}

The Region of Durham's direct farm marketing association, Durham Farm Fresh, promotes many successful agri-tourism operations and provide local food purchasing options from on-farm markets and stores (Durham Farm Fresh, n.d.). Brooks Farms, located just north and west of the Township of Uxbridge, has become regarded as one of the prime destinations for agri-tourism in the Province. They offer a farmer's market, pick-your-own, school tours, special events, on-farm café and more. Brooks Farms started in operation in 1800's but did not start the direct farm marketing aspect of the business until the early 1990's. Since then, they have seen increases in visitors by the thousands each year (Brooks Farms, n.d.). The town of Uxbridge capitalized on the traffic generated by Brooks Farms by placing a strategic series of wayfinding signs near the farm. The Township of Uxbridge worked with Central Counties Tourism to design and implement this signage strategy to encourage visitors to travel to other local destinations and shops in the area (Central Counties Tourism, 2017).

Just a short drive away from Brooks Farms is Willowtree Farms, located outside of Port Perry in the Township of Scugog. Willowtree Farms has seen tremendous growth in the last year alone opening a newly constructed farmer's market, store and restaurant with on-farm processing capabilities. In addition, they expanded their cropping to grow over thirty different fruits and vegetables on almost six hundred acres of land. They also have a CSA program and weekly menu pick-ups. Willowtree Farms offers pick-your-own adventures, a petting zoo and more. This recent growth would not have been possible without the increased interest in buying local and the proximity to the GTA market. Willowtree Farms has been able to almost double their employees and expand their product lines to include more preserves and baked items made onsite (Willowtree Farms, n.d.).

In the Township of Brock, Julie Belli, owner of Carpe Diem Farm has expanded her operation significantly. Julie Belli is an award-winning artisan cheese maker and tireless advocate of using organic practices to cultivate fresh local food. Belli is known as Durham Region's only female artisan cheese maker, she has used this skill to help get her business off the ground and established herself in Durham Region and beyond by attending farmers' markets and getting to know her customers personally. In the last year Belli purchased a new property located along the Trans-Canada Highway and set-up her very own café and on-farm-market. An interview with Julie Belli in June 2017 revealed plans to expand upon her success in the realm of direct-farm marketing to offer cooking classes, food safety certification courses and opportunities for people to try their hand at farming through immersive education and experience (Durham Farm Fresh Carpe Diem Farm, n.d.). Belli has proven to be a poster child for the rise of the local food movement and demonstrated a positive impact for north Durham and the Township of Brock inparticular. Belli has become involved in the Brock Board of Trade and encouraged partnerships with other business owners to help promote one another and enhance the economic impact of consumers visiting the area. Belli reports that over 90,000 travelers drive the Trans-Canada 
Highway on a summer weekend and if she can even capture a small percentage of that market she considers it a success (Durham Farm Fresh - Carpe Diem Farm, n.d.).

\section{Economic Success Stories of Local Food in Durham Region continued...}

Brooks Farms, Willowtree Farms and Carpe Diem Farm all demonstrate some of the economic success due to the rise of the local food movement, whether it is the trickle-down effect of consumers supporting other local businesses, the expansion of employees and product lines or generating more money in the pockets of local producers. Another offshoot of the movement's increased popularity is the expanding aspect of recreational engagement. Gale argues the multiplier effect of local food through agri-tourism by pointing out that often visitors are coming to the area for overnight stays, which can more than double spending in the community (Gale, 2013).

The rise of the local food movement also has a trickle-down effect by increasing local employment in rural communities. An example is Willowtree Farms; the farm has been able to increase their workforce significantly. Additionally, their new on-farm market and store has allowed them to introduce products other than local food like hand-made items from local business owners, artisans and entrepreneurs. All these products are in keeping with the local theme and goes beyond local food resulting in a more positive and supportive local business climate.

There is a verified perception that local food costs more for consumers considering the increase in employment, not just as farm labourers but as managers, communications specialists and agribusiness financial advisors (Schwartz, 2009). With growing demand for local food, businesses are finding more ways to promote themselves, often requiring additional staff time and resources. Brooks Farms for instance, has hired full-time communications coordinators and graphic designers that keep the website up-to-date with seasonal initiatives, and campaigns.

The sale of local food also results in additional economic benefit through premium prices. Many direct marketed local food items are classified as specialty products and therefore can be sold for an increased price. Often, they are sold through alternative channels or appeal to more diverse markets. This can be particularly beneficial for producers who travel to farmers markets in culturally diverse urban centers. As a rule of thumb, these specialty products bring a higher return per acre which is beneficial for producers and rural communities (Gale, 2013).

\section{Conclusion}

The impact of the local food movement has been seen across the United States, the United Kingdom, and beyond. Living in Canada provides opportunities to grow produce that can be enjoyed seasonally, including during the winter months. Over the last few years, the Province of 
Ontario has shown a commitment to invest and focus on local food which has resulted in great success. The Golden Horseshoe area of Ontario is named as one of the up and coming food processing areas in North America and Durham Region, being one of the largest in land area and second for gross farm receipts, has tremendous potential for further growth in the local food sector. The Durham Region has a current population of approximately 650,000 and is expected to reach almost 800,000 by 2020. (The Regional Municipality of Durham, 2016). This significant growth in a short amount of time means there will continue to be opportunities for producers and direct farm marketing operations to cater to an even larger consumer base who enjoy eating locally grown produce.

Local food can have different meanings for different people but the most common characteristic is geography and a genuine connection between producer and consumer. The definition can also change depending on how densely populated an area is and what ratio of urban to rural residents in a radius. Durham Region has many examples of farms that have seen success over the last several years due to the rise of the local food movement; they are a testament to the benefits of being a rural business within proximity to a more densely populated area.

The economic impacts discussed in this paper such as; direct flow of income from consumer to producer, increased employment, support for wider buy local campaigns, increased local circulation of money and the rise of specialty products for niche markets will continue to be impactful as Durham Region grows. The rural communities of Uxbridge, Scugog and Brock will continue to see an influx of urban consumers looking to connect with producers and learn about where their food comes from. The recreation aspect of local food, in the form of agri-tourism, has proven to have a positive influence on the local food movement and its impact on rural communities.

\section{Author biography}

Stacey Jibb was raised on a dairy farm near the small town of Sunderland, Ontario in the Region of Durham. She attended Wilfrid Laurier University and obtained an Honours Bachelor of Arts Degree majoring in Communication Studies. Following graduation, she completed a PostGraduate Degree in Paralegal Studies at Durham College In 2015, Stacey obtained a position with the Region of Durham's Economic Development and Tourism Division. In her current role as the Rural Economic Development Coordinator, Stacey works closely with Durham's three rural municipalities coordinating economic development programs and initiatives. 


\section{References}

About Farmers Market Ontario. (n.d.). Retrieved July 27, 2017, from http://farmersmarketsontario.com/about-farmers-markets-ontario/

Bain, J., Chen, Y., Cole, J., Gong, S., Matthews, J., Smith, J., . . Whiteman, N. (2013, November). What does local food mean to you? (Rep.). Retrieved July 22, 2017, from Cultural and Production Research Group, University of Leicester website:

https://www2.le.ac.uk/departments/media/news-and-journalism-documents/report-what-doeslocal-food-mean-to-you

Bill 36, Local Food Act, 2013. (2013, November 6). Retrieved July 22, 2017, from https://www.ola.org/en/legislative-business/bills/parliament-40/session-2/bill-36

Brian, R. (2012, September). The Local Food Movement: Definitions, Benefits and resources. Utah State University Extension Sustainability, 1-4. doi:https://digitalcommons.usu.edu/cgi/viewcontent.cgi?article=2693\&context=extension_curall Brooks Farms. Brooks Farms - About Us. (n.d.). Retrieved July 22, 2017, from https://www.brooksfarms.com/

Canadian Public Trust Research: With Insights from Moms, Millennials and Foodies (Rep.). (2016). Retrieved July 22, 2017, from Canadian Centre for Food Integrity website: http://www.foodintegrity.ca/wp-content/uploads/2017/05/2016-Public-Trust-ResearchReport.pdf

Central Counties Tourism. (2017). Township of Uxbridge Tourism Wayfinding Plan. Markham, Ontario. Retrieved from http://centralcounties.ca/wpcontent/uploads/Municipal_Tourism_Wayfinding_Info_Sheet.pdf

Collins, D., Kelly, J., \& Pate, E. (2011, February). Direct Farm Marketing in Ontario (Canada, Ontario Ministry of Agriculture, Food and Rural Affairs, Province of Ontario). Retrieved July 27, 2017, from http://www.omafra.gov.on.ca/english/busdev/facts/16-025.html.

Durham Farm Fresh. Welcome to Durham Farm Fresh. (n.d.). Retrieved July 22, 2017, from https://durhamfarmfresh.ca

Elton, S. (2010). Locavore: From farmers fields to rooftop gardens, How Canadians are changing the way we eat. Toronto, ON: Harper Collins.

Food Labelling Modernization Initiative. (2016, December 01). Retrieved July 22, 2017, from http://www.inspection.gc.ca/food/general-food-requirements-and-guidance/labelling/labellingmodernization-initiative/eng/1370111174659/1370111346666 
Foodland Ontario - About Us. (2012). Retrieved July 26, 2017, from https://www.ontario.ca/foodland/page/about-usGale, F. (2013).

Direct Farm Marketing as a Rural Development Tool. Rural Development Perspectives, 12(2), 2013th ser. Retrieved July 22, 2017, from https://usda.library.cornell.edu/.

Durham Farm Fresh - Carpe Diem Farm \& Café. (n.d.) Retrieved July 2017, from https://durhamfarmfresh.ca/member/carpe-diem-farm-cafe/

Grubinger, V. (). Ten Reasons to Buy Local. University of Vermont Extension. Retrieved July 27, 2017, from https://www.uvm.edu/vtvegandberry/factsheets/buylocal.html

Martinez, S. (2010). Local Food Systems: Concepts, Impacts, and Issues (Economic Research Report No. 97). Darby, PA: Diane Publishing.

Locavore. (2005). In Merriam-Webster. Retrieved July 27, 2017, from https://www.merriamwebster.com/dictionary/locavore

The Regional Municipality of Durham, Economic Development and Planning Department. (2016, October 26). Monitoring Growth Trends. Retrieved July 31, 2017, from https://www.durham.ca/departments/planed/planning/stats-n-facts/2016-INFO-33.pdf.

Canada, Ontario Ministry of Agriculture, Food and Rural Affairs, Province of Ontario. (2016). Ontario Ministry of Agriculture, Food and Rural Affairs. Retrieved July 27, 2017, from http://www.omafra.gov.on.ca/english/about/local_food_rpt16.pdf

Reynolds, J. (2016). Buying Local Food Products. Food Service and Nutrition, 1(3), 2016th ser., 5-8. Retrieved July 27, 2017, from http://www.nxtbook.com/naylor/CSNQ/CSNQ0416/index.php?startid=5 - /4 - /2\#/0

Schwartz, J. D. (2009, June 11). Buying Local: How it boosts the economy. TIME. Retrieved July 22, 2017, from http://content.time.com/time/business/article/0,8599,1903632,00.html

Willow Tree Farms - Our Story. (n.d.). Retrieved July 22, 2017, from https://willowtreefarm.ca/our-story/ 